\title{
The ethics of Soviet medical practice: behaviours and attitudes of physicians in Soviet Estonia
}

\author{
Donald A Barr Stanford University, California, USA
}

\begin{abstract}
Objectives-To study and report the attitudes and practices of physicians in a former Soviet republic regarding issues pertaining to patients' rights, physician negligence and the acceptance of gratuities from patients. Design-Survey questionnaire administered to physicians in 1991 at the time of the Soviet breakup. Setting-Estonia, formerly a Soviet republic, now an independent state.
\end{abstract}

Survey sample-A stratified, random sample of 1,000 physicians, representing approximately 20 per cent of practising physicians under the age of 65 .

Results-Most physicians shared information with patients about treatment risks and alternatives, with the exception of cancer patients: only a third of physicians tell the patient when cancer is suspected. Current practice at the time of the survey left patients few options when physician negligence occurred; most physicians feel that under a reformed system physician negligence should be handled within the local facility rather than by the government. It was common practice for physicians to receive gifts, tips, or preferential access to scarce consumer goods from their patients. Responses varied somewhat by facility and physician nationality.

Conclusion-The ethics of Soviet medical practice were different in a number of ways from generally accepted norms in Western countries. Physicians' attitudes about the need for ethical reform suggest that there will be movement in Estonia towards a system of medical ethics that more closely approximates those in the West.

The breakup of the Soviet Union in 1991 provided an opportunity to explore aspects of Soviet health care of which we in the West had little prior understanding. The ethics that guided Soviet medical practice was one of the areas we knew little about. Using data from a survey of physicians in Estonia at the time of the Soviet breakup, this paper explores attitudes towards ethical issues as well as actual patterns of practice in one of the former Soviet republics. While the responses directly reflect only

\section{Key words}

Medical ethics; USSR; Russia; Estonia. the specific situation in Estonia, they indirectly provide a reflection of the broader system of 'Soviet socialized medicine' (1) that was imposed throughout the former Soviet republics (2).

Prior to the Gorbachev era, Western interest in Soviet medical ethics focused primarily on the ethics of Soviet psychiatry. Political dissidents were frequently classified as mentally ill simply for expressing their opposition to state policies (3-5). Psychiatric hospitals functioned as prisons for these dissidents, classified as suffering from 'sluggish schizophrenia', a condition recognised only by Soviet psychiatrists (6). These practices led to inter $\Omega$ national condemnation of Soviet psychiatry, and the withdrawal of the Russian Psychiatric Society fromb the World Psychiatric Association in the face of its? impending expulsion (7).

During the period of perestroika in the late 1980s, physicians and ethicists initiated a dialogue about Soviet attitudes and policies regarding broader issues in medical ethics (8-11). These discussions remained largely abstract and descriptive, presenting little empirical information about actual clinical attitudes and practices. Similarly, more recent discussions of Soviet ethical practices draw broad general conclusions without presenting supporting data (12). This paper presents data pertaining to three key issues of medical ethics as they existed in Estonia at the time of the Soviet collapse: recognition of patients' rights pertaining to treatment; attitudes and practices regarding adverse outcomes from treatment possibly related to physician negligence, and physicians' acceptance of cash or other goods from patients as 'tips'. These data were gathered as part of a survey of a stratified random sample of nearly 20 per cent of the physicians practising in Estonia in 1991.

\section{Survey methods}

Using a list of all physicians practising in Estonia in 1991 (excluding those in the military and the KGB), a stratified random sample of 1,000 physicians was selected for survey. Stratification criteria included age, sex, and ethnicity. Each physician was visited at her/his place of work and offered a survey question- 
Table 1 Current practices regarding patients' rights

\begin{tabular}{|c|c|c|c|c|}
\hline & Almost never & Seldom & Sometimes & Always \\
\hline $\begin{array}{l}\text { If a treatment has some risk of a bad outcome, how often does the doctor tell the } \\
\text { patient this before beginning treatment? }\end{array}$ & $3 \%$ & $7 \%$ & $28 \%$ & $62 \%$ \\
\hline $\begin{array}{l}\text { If there is more than one way to treat a patient, how often does the doctor discuss the } \\
\text { possible choices of treatment with the patient? }\end{array}$ & $6 \%$ & $16 \%$ & $42 \%$ & $36 \%$ \\
\hline $\begin{array}{l}\text { If a patient will probably have a bad outcome from a disease, how often does the } \\
\text { doctor inform the patient of this? }\end{array}$ & $6 \%$ & $12 \%$ & $35 \%$ & $47 \%$ \\
\hline $\begin{array}{l}\text { If a doctor thinks a patient has cancer, how often does the doctor tell this to the } \\
\text { patient? }\end{array}$ & $42 \%$ & $22 \%$ & $26 \%$ & $10 \%$ \\
\hline $\begin{array}{l}\text { If a doctor discusses a patient's medical condition with the friends or family members } \\
\text { of a patient, how often does the doctor first get permission from the patient? }\end{array}$ & $50 \%$ & $21 \%$ & $17 \%$ & $12 \%$ \\
\hline $\begin{array}{l}\text { If a patient wishes to examine the written record of his or her care, how often is this } \\
\text { allowed? }\end{array}$ & $52 \%$ & $19 \%$ & $15 \%$ & $14 \%$ \\
\hline $\begin{array}{l}\text { If a patient does not want to have a treatment, even if refusing treatment will lead to a } \\
\text { bad outcome for the patient, how often is the patient allowed to refuse the } \\
\text { treatment? }\end{array}$ & $6 \%$ & $13 \%$ & $21 \%$ & $60 \%$ \\
\hline $\begin{array}{l}\text { If a patient wishes to get the opinion of another doctor before agreeing to treatment, } \\
\text { how often does the first doctor agree to this? }\end{array}$ & $4 \%$ & $7 \%$ & $19 \%$ & $70 \%$ \\
\hline
\end{tabular}

naire in the language of her/his choice (Estonian or Russian). The survey took approximately one hour to complete. Each physician provided informed consent prior to survey participation. Of the 1,000 physicians in the survey sample, survey workers were able to locate 880 ; of these, 792 completed the survey, constituting a response rate of 79 per cent of the original sample and 90 per cent of physicians actually contacted. Further details about survey methodology are available elsewhere (13). Responses are presented below to questions pertaining to three areas of medical practice: the recognition of patients' rights; policies regarding physician negligence, and the issue of physicians accepting 'tips' or other gratuities from patients in addition to their official state salary.

\section{Patients' rights}

In the United States and many other Western countries, patients benefit from a number of rights, many of them formally embodied in the law. These include a right to informed consent regarding treatment, risks, options, and prognosis; a right to confidentiality; a right to a second opinion; a right to obtain or examine copies of the medical record, and a right to refuse treatment.

Under the Soviet system, there was little official acknowledgment of a patient's right to know. The general perception is that Soviet patients rarely received the information Western patients have come to expect (12). In order to understand the extent to which these rights were observed in actual practice, physicians in Estonia were asked how often certain practices pertaining to these rights occurred. Their responses are presented in table 1.

If there was a possibility that a recommended treatment could have a bad outcome, usually patients were informed of the risk ahead of time, though for a substantial minority of patients this was not the case. Explaining alternative treatment options to patients happened consistently only about a third of the time.
The issue of discussing a poor prognosis with a patient depended on whether the case involved cancer. More than 80 per cent of patients were likely to be informed of a poor prognosis. However, if the case involved cancer, the patient was likely to be informed only 36 per cent of the time; 42 per cent of patients with cancer were never told of their diagnosis. This finding is consistent with what appears to be a general hesitation on the part of Soviet physicians to discuss cancer with a patient. As explaine $\$$ by a Russian ethicist:

'Patients are not informed of a terminal diagnosi because, it is felt, they do not have the knowledge to understand; they have no role in "medical" decisions; and they need protection from the trauma of the bad news' (14).

Estonia has a highly regarded National Cancer Institute. According to its director, high party officials from Moscow were often sent there for treatment. He explained that it was also common for physicians in Estonia to send patients to the cancer institute for treatment without telling the patients why they were being referred. Patients knew what the institute was, and generally got the idea without having their diagnosis actually explained to them ahead of time. How often patients referred to the National Cancer Institute turned out not to have cancer is not known.

It appears that physicians seldom worried about obtaining consent from patients before discussing their case with friends or family. Likewise patients were seldom allowed to see what was in their medical record. However, if a patient wished to obtain a second opinion before obtaining treatment, these wishes were respected nearly 90 per cent of the time. In 60 per cent of cases, patients who wished to refuse treatment were always allowed to do so, even if refusing treatment would lead to a bad outcome for the patient. In nearly 20 per cent of cases, however, patients who refused treatment were given treatment nonetheless. 
Table 2 Differences in patients' rights by type of facility

\begin{tabular}{|c|c|c|c|c|c|}
\hline How often does a doctor: & Almost never & Seldom & Sometimes & Always & Likelihood ratio \\
\hline \multicolumn{6}{|l|}{ Inform the patient of treatment risks? } \\
\hline polyclinic & $1 \%$ & $6 \%$ & $31 \%$ & $62 \%$ & $\mathrm{n}=0.08$ \\
\hline hospital & $4 \%$ & $9 \%$ & $28 \%$ & $60 \%$ & $p=0.08$ \\
\hline \multicolumn{6}{|l|}{ Inform the patient about treatment options? } \\
\hline polyclinic & $4 \%$ & $14 \%$ & $43 \%$ & $40 \%$ & $0<0.01$ \\
\hline hospital & $9 \%$ & $20 \%$ & $38 \%$ & $33 \%$ & $p<0.01$ \\
\hline \multicolumn{6}{|l|}{ Inform the patient of a poor prognosis (other than cancer)? } \\
\hline $\begin{array}{l}\text { polyclinic } \\
\text { hospital }\end{array}$ & $4 \%$ & $13 \%$ & $28 \%$ & $55 \%$ & $p=0.02$ \\
\hline \multicolumn{6}{|l|}{$\begin{array}{l}\text { hospital } \\
\text { Agree to obtain a second opinion? }\end{array}$} \\
\hline $\begin{array}{l}\text { polyclinic } \\
\text { hospital }\end{array}$ & $\begin{array}{l}1 \% \\
7 \%\end{array}$ & $\begin{array}{r}3 \% \\
11 \%\end{array}$ & $\begin{array}{l}18 \% \\
18 \%\end{array}$ & $\begin{array}{l}78 \% \\
64 \%\end{array}$ & $\mathrm{p}<0.01$ \\
\hline \multicolumn{6}{|l|}{ Allow the patient to review the medical record? } \\
\hline $\begin{array}{l}\text { polyclinic } \\
\text { hospital }\end{array}$ & $\begin{array}{l}36 \% \\
69 \%\end{array}$ & $\begin{array}{l}22 \% \\
12 \%\end{array}$ & $\begin{array}{l}21 \% \\
11 \%\end{array}$ & $\begin{array}{r}21 \% \\
8 \%\end{array}$ & $\mathrm{p}<0.01$ \\
\hline
\end{tabular}

In the Soviet medical care system, there was a distinct separation between hospitals and outpatient polyclinics. Physicians seldom worked in both types of facility. Patients sent from a polyclinic to a hospital would have a new physician take over their case. The above data on ethical practices were reexamined using $\chi^{2}$ analysis to determine if ethical practices differed substantially in polyclinics and hospitals. For five of the eight questions significant differences were shown to exist in the ethical practices of physicians in polyclinics and hospitals. These results are shown in table 2 . A clear pattern results, with patients in polyclinics more likely than those in hospitals to receive pertinent information, access to medical records, or a second opinion.

\section{Physician negligence}

The next area to be explored is that of responses to bad outcomes for patients and the issue of physician negligence. There were few formal quality assurance or peer review activities under the Soviet system. In interviews with physicians there, most had little information about how often negligence occurred or how it was handled, although there was general agreement that there were negligent physicians still in practice.

As part of the survey, physicians were asked to indicate current practice at their facility in four situations: when a patient wishes to complain about a physician's care; when there is a bad outcome for a patient irrespective of cause; when there is a bad outcome caused by physician negligence, and when a physician exhibits gross negligence or a repeated pattern of negligence. They were then asked what, in their opinion, should be done in these situations once Estonia had been able to reform its health care system in the post-Soviet period. Tables 3-6 compare current practice with opinions about needed reforms; they also compare opinions aboug needed reforms between ethnic Estonians and ethnie Russians (including other non-Estonian ethnicities practising in Estonia.

When a patient wished to complain about a doctor's care, he or she had little recourse beyond bringing the complaint either to the department chief or the medical director of the facility; most complaints were handled within the department. When it came to the question of a reformed system physicians split on this issue, with 31 per cent feeling that the medical society should handle patient complaints, and 58 per cent feeling that the complaint should be handled within the department.

When a medical treatment led to a bad outcome for a patient, patients usually got either an explanation alone (39 per cent) or an explanation and an apology ( 55 per cent). There was no mechanism for patients to receive monetary compensation for the bad outcome. Under a new system, 43 per cent of physicians feel that a patient injured by treatment should receive monetary compensation.

Table 3 What things (is) should a patient be able to do under a new system if he or she feels that a doctor has given bad care?

\begin{tabular}{|c|c|c|c|c|}
\hline \multirow[b]{2}{*}{ Response } & \multirow[b]{2}{*}{$\begin{array}{l}\text { Current } \\
\text { practice }\end{array}$} & \multirow[b]{2}{*}{$\begin{array}{l}\text { New } \\
\text { system }\end{array}$} & \multicolumn{2}{|c|}{$p<0.01$} \\
\hline & & & Estonian & $\begin{array}{l}\text { Russian } \\
\text { and other }\end{array}$ \\
\hline $\begin{array}{l}1 \text { There is nothing the patient (is) should be able to do. } \\
2 \text { The patient (is) should be able to complain to the chief doctor of the department. } \\
3 \text { The patient (is) should be able to complain to the chief doctor of the polyclinic or } \\
\text { hospital. }\end{array}$ & $\begin{array}{r}4 \% \\
72 \% \\
21 \%\end{array}$ & $\begin{array}{r}1 \% \\
58 \% \\
9 \%\end{array}$ & $\begin{array}{r}0 \% \\
62 \% \\
10 \%\end{array}$ & $\begin{array}{r}1 \% \\
50 \% \\
8 \%\end{array}$ \\
\hline $\begin{array}{l}4 \text { The patient (is) should be able to complain to an official in the Health Ministry. } \\
5 \text { The patient (is) should be able to complain to the doctor's professional society. }\end{array}$ & $\begin{array}{l}3 \% \\
0 \%\end{array}$ & $\begin{array}{r}1 \% \\
31 \%\end{array}$ & $\begin{array}{r}0 \% \\
28 \%\end{array}$ & $\begin{array}{r}2 \% \\
39 \%\end{array}$ \\
\hline
\end{tabular}


Table 4 What (is) should be done for the patient or the patient's family under a new system if a treatment leads to a bad outcome for the patient?

\begin{tabular}{|c|c|c|c|c|}
\hline \multirow[b]{2}{*}{ Response } & \multirow[b]{2}{*}{$\begin{array}{l}\text { Current } \\
\text { practice }\end{array}$} & \multirow[b]{2}{*}{$\begin{array}{c}\text { New } \\
\text { system }\end{array}$} & \multicolumn{2}{|c|}{$p<0.01$} \\
\hline & & & Estonian & $\begin{array}{l}\text { Russian } \\
\text { and other }\end{array}$ \\
\hline \multirow{5}{*}{$\begin{array}{l}1 \text { Nothing (is) should be done. } \\
2 \text { The patient or the family (does) should receive an explanation but not an apology. } \\
3 \text { The patient or the family (does) should receive an explanation and an apology. } \\
4 \text { The patient or the family (does) should receive an explanation, an apology, and } \\
\text { some money. }\end{array}$} & $6 \%$ & $0 \%$ & $0 \%$ & $0 \%$ \\
\hline & $39 \%$ & $9 \%$ & $11 \%$ & $5 \%$ \\
\hline & $55 \%$ & $48 \%$ & $49 \%$ & $44 \%$ \\
\hline & $0 \%$ & $43 \%$ & $40 \%$ & $50 \%$ \\
\hline & $0 \%$ & $45 \%$ & $40 \%$ & $30 \%$ \\
\hline
\end{tabular}

If a physician made a mistake leading to a bad outcome for a patient, the problem was usually handled by the department chief. As with patient complaints, there was no mechanism for anyone outside the facility to review a doctor's care when a mistake occurred. Under a new system, 19 per cent of physicians feel that the medical society should review the care of negligent physicians.

When a doctor committed a serious error or made a series of mistakes, response was typically in he form of a reprimand (66 per cent), with doctors required to take additional training 20 per cent of the time. Seldom were doctors required to stop practising when this occurred. Under a new system, 13 per cent of doctors think that licence revocation would be appropriate in these cases. Most doctors (63 per cent) think these physicians should be required to take additional training, but should be allowed to continue to practise.

Two additional points should be made about these data. In the case of both patient complaints and physician negligence, there is nearly unanimous agreement that the government should have no role in monitoring or controlling physician behaviour. Those physicians who believe these issues should be handled by an authority outside the facility feel this job is one for the medical society. Under Soviet rule, the Estonian Medical Association was outlawed. When Estonia declared its independence from the Soviet Union, the Estonian Medical Association was re-established, with the same logo, the same journal (including sequential volume numbering), and the same structure it had prior to the Soviet period. There appears to be a commonly held trust that this association represents the interests and beliefs of physicians.

Secondly, it is interesting to note that ethnic Russians practising in Estonia take a somewhat more strident view than ethnic Estonians of the appropriate response to physician negligence. Using $\chi^{2}$ analysis, Russians are more likely to be of the opinion that the medical society rather than the locab facility should deal with patient complaints an physician negligence $(\mathrm{p}<0.01$, likelihood ratio $)$ They are also more likely to believe that patients should receive monetary compensation for adverse treatment outcomes $(p<0.01)$ and that physicians who exhibit gross negligence should lose their medical licence $(p=0.03)$. It appears that Russians tend to put more trust in central authority to handle physician negligence, while Estonians prefer local autonomy to deal with these issues.

Table 5 What (is) should be done under a new system if a doctor makes a mistake in treatment and there is a bad outcome for the patient?

\begin{tabular}{|c|c|c|c|c|}
\hline \multirow[b]{2}{*}{ Response } & \multirow[b]{2}{*}{$\begin{array}{l}\text { Current } \\
\text { practice }\end{array}$} & \multirow[b]{2}{*}{$\begin{array}{c}\text { New } \\
\text { system }\end{array}$} & \multicolumn{2}{|c|}{$p<0.01$} \\
\hline & & & Estonian & $\begin{array}{l}\text { Russian } \\
\text { and other }\end{array}$ \\
\hline 1 Nothing (is) should be done. & $10 \%$ & $0 \%$ & $0 \%$ & $0 \%$ \\
\hline 2 The chief doctor in the department (does) should review the doctor's care. & $76 \%$ & $67 \%$ & $75 \%$ & $52 \%$ \\
\hline 3 The chief doctor of the polyclinic or hospital (does) should review the doctor's care. & $13 \%$ & $11 \%$ & $12 \%$ & $9 \%$ \\
\hline 4 An official of the health ministry (does) should review the doctor's care. & $1 \%$ & $3 \%$ & $3 \%$ & $2 \%$ \\
\hline 5 A representative of a professional society (does) should review the doctor's care. & $0 \%$ & $19 \%$ & $10 \%$ & $37 \%$ \\
\hline
\end{tabular}

Table 6 What (is) should be done under a new system if a doctor makes a very bad mistake or a series of mistakes?

\begin{tabular}{|c|c|c|c|c|}
\hline \multirow[b]{2}{*}{ Response } & \multirow[b]{2}{*}{$\begin{array}{l}\text { Current } \\
\text { practice }\end{array}$} & \multirow[b]{2}{*}{$\begin{array}{c}\text { New } \\
\text { system }\end{array}$} & \multicolumn{2}{|c|}{$p<0.03$} \\
\hline & & & Estonian & $\begin{array}{l}\text { Russian } \\
\text { and other }\end{array}$ \\
\hline 1 Nothing (is) should be done. & $4 \%$ & $0 \%$ & $0 \%$ & $0 \%$ \\
\hline 2 The doctor (is) should be reprimanded and told how to give good care. & $66 \%$ & $17 \%$ & $19 \%$ & $13 \%$ \\
\hline 3 The doctor (is) should be required to take extra training. & $20 \%$ & $63 \%$ & $64 \%$ & $62 \%$ \\
\hline 4 The doctor (is) should have his or her care supervised by another doctor. & $4 \%$ & $7 \%$ & $6 \%$ & $10 \%$ \\
\hline 5 The doctor (is) should be required to stop treating patients. & $6 \%$ & $13 \%$ & $11 \%$ & $15 \%$ \\
\hline
\end{tabular}


Table 7 Frequency and type of goods received from patients

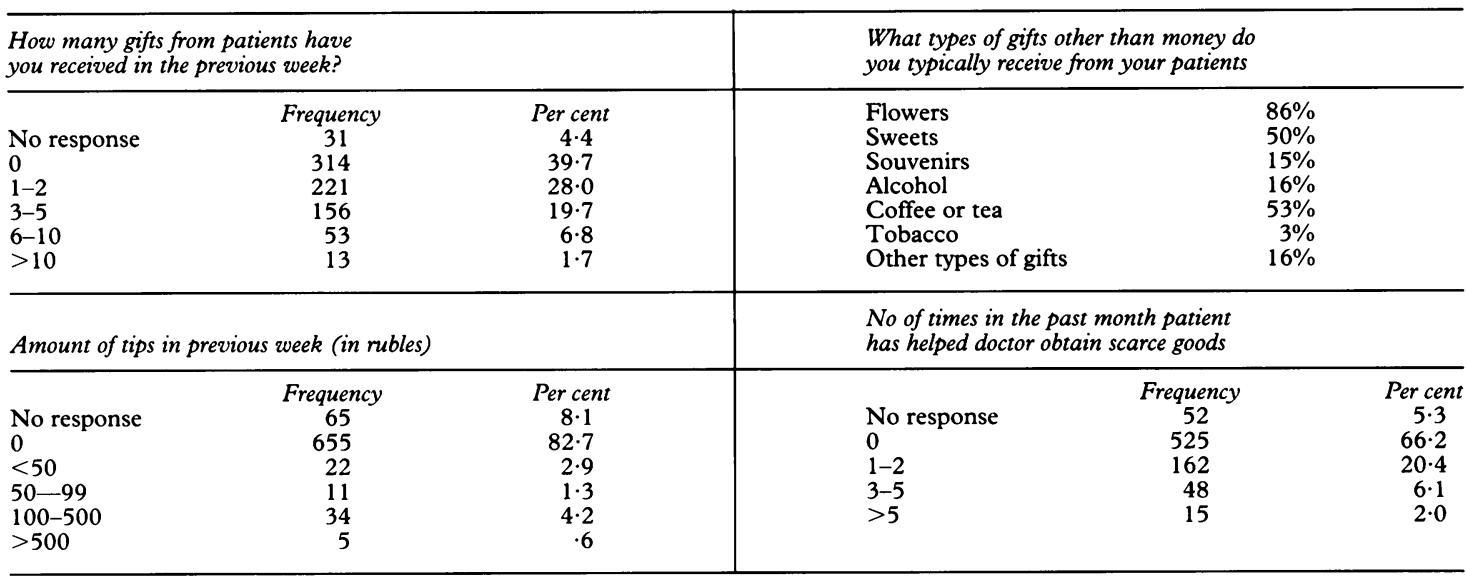

\section{Physicians' 'tips'}

The final issue for examination is the frequency with which physicians received extra compensation from their patients in the form of gifts, cash, or preferential access to scarce goods. With rare exceptions, all care in the Soviet Union was free to patients, and all physicians were paid a salary. For political reasons, physician salaries were kept quite low, typically 70-80 per cent of the average salary of a factory worker (15). Survey data indicate that there was little variation in physician salaries, with only a 26 per cent difference between 75 th and 25 th percentiles. In order to supplement their rather meagre salaries, it became common practice for physicians to receive (some would say expect) either cash or consumer goods from their patients. As explained by Ryan:

'Many medical personnel have an enhanced command over resources by virtue of gifts from patients in cash or in kind. The latter, incidentally, assume an enhanced value in an economy where the supply of many consumer goods and services is characterized by endemic deficiencies in quality and quantity' (16).

Physicians were asked how often they had recently received various types of gifts from their patients. Their responses are shown in table 7.

Sixty per cent of physicians reported receiving at least one non-cash gift from a patient in the previous week. On average, a doctor received about two gifts a week. Fifteen per cent of physicians had received money from their patients in the form of tips in the previous week. For those who received at least one tip, the average amount received in tips during the week was 185 rubles (at a time when the average monthly salary was 1,000 rubles). Thirty per cent of physicians reported having obtained access to scarce goods such as food and clothing through their patients at least once during the previous month.
(Interviews with physicians indicated that these goods often would be put aside by shopkeepers for their preferred customers, such as their doctor.) For those obtaining such goods, the average number of times they did so in the previous month was three.

It seems that extra payment from patients was the rule for physicians in Estonia. In preliminary interviews, physicians did not seem embarrassed abou receiving these payments. Only 5-10 per cent of the 792 physicians surveyed failed to answer the question about extra payments.

\section{Discussion}

The general picture that emerges from these data is of a medical profession that assumed a somewhat parental role towards its patients. To a Soviet physician, it was not necessary to inform a patient of risks associated with treatment, other treatment alternatives, or a poor prognosis associated with the patient's condition. The Soviet attitude towards cancer speaks for itself. Likewise, physicians seemed to discuss a patient's condition freely with others without first obtaining the patient's consent. Finally, even when a patient refused treatment, in many instances the physician would continue that treatment.

By Western standards, these behaviours are easily seen as violating patients' rights. However, Soviet society was not one that placed a great deal of import on individual rights and freedoms. Compared to individual political rights, patients' rights regarding medical care more closely approximated what patients in the West have come to expect. As the Soviet health care system undergoes reform, it would seem to be important to achieve consensus on what patients can rightly expect in the areas of informed consent, full disclosure of medical information, confidentiality, and refusal of treatment. Policy-makers may want to consider giving patients or their advocates an important role in these discussions. 
There seems to be substantial sentiment among physicians that a more rigorous system of quality assurance and peer review needs to be established. There are few mechanisms to deal with physician negligence when it arises, and no mechanisms to identify negligent physicians before they cause harm. Gorbachev's first minister of health, Evgeni Chazov, was quite frank in acknowledging the low level of knowledge and skills of many Soviet physicians (17). The questionable and variable quality of available care was well known to patients. More than 50 per cent of people in Russia are dissatisfied with their current health care system, and especially with the attitudes and moral standards of physicians (18).

Current practice as well as current majority opinion is that issues of physician negligence and patient harm should be handled within the local facility, preferably within the department in which it occurs. Unfortunately, this situation presents two potential ethical problems. Physicians in many Western countries have not historically demonstrated an ability to police themselves rigorously in the absence of some outside authority. There is little reason to think that Estonian or Russian physicians would be able to do a better job. In addition, leaving the enforcement of quality standards to the local facility involves wide variability in the standards used to assess physicians' actions. Without some more general authority playing a central role in developing quality assurance mechanisms, there would be few means to develop generally applicable standards of care, a necessary step before patients' trust in the medical profession can be increased.

There appears to be a consensus regarding what body should have responsibility for monitoring physician behaviour. If a strong central authority is needed, physicians believe it should be their professional medical society and not a government agency. The abuse of power endemic in the Soviet bureaucracy has left a near unanimous distrust of government's ability to monitor medical care fairly or effectively. Additionally, there appears to be a growing consensus that some form of monetary compensation should be established for patients injured as a result of medical care. Whether this should come in the form of a malpractice tort system or a no-fault system of compensation is a question that warrants attention.

The issue of physicians accepting tips from their patients is a complex one, and has implications that vary with the perspective one adopts. The system of 'under the table payments' to doctors was widespread in the Soviet Union (19) and other Sovietdominated countries $(20,21)$. Field addresses how we should view these payments.

'The fine point, and one that cannot be determined, is whether these payments, whether solicited, requested, or hinted at should be regarded as bribes for preferential treatment or tokens of gratitude or both. But perhaps, more than anything else, they constitute a countervailing power at the disposal of the patient to exert some type of control over the physician' (22).

Before attempting to answer the question posed by Field, it is important to consider two anecdotes recently reported in the press. One occurred in the former Soviet Union; one occurred in the US.

A legislative representative reported that it had become common for surgeons in her district to expect a payment of $\$ 500$ for an operation over and above what the government health plan pays. 'Everyone knows about this,' the legislator contends, 'but no one says anything' (23).

An elderly man with a bad back consulted a specialist and was told he must first sign a contract agreeing to pay the doctor a fee in addition to what the government health plan would pay. "They said, "If you don't sign we won't service you"', the patient reports. 'Look, you've been referred to this doctor as the best. You're anxious. You're sick. You'd probably give him your right arm. And you're certainly not going to cause trouble and question him' (24).

In the United States, as in the Soviet Union and its successor states, many doctors are not satisfied with what the government health plan pays for treat- 8 ment. In the former Soviet states, where most doctors are still paid a salary by the government, expecting extra payment as a condition of treatment is often equated with demanding a bribe (25). In the US, such practice is called good business and is supported by many medical societies (24).

The report of the surgeons extracting extra fees comes from Azerbaijan. (The amount was actually 500 rubles.) The back specialist who won't see a patient who doesn't agree to pay extra practises in New York. It is not easy for this author to differentiate between these two practices on ethical grounds.

The question to consider, then, is how we are to view physicians in the former Soviet Union who expect extra payment from their patients as a condition of good treatment (and, how we should view the back surgeon in New York). Under Marxist-Leninist dogma, all workers in the Soviet Union were paid a salary by the state that reflected the position of that occupation in society. For a physician to expect or even to accept a separate fee for treating a patient was officially classified as bourgeois and unethical.

By comparison, payment as a condition of treatment is at the economic core of the system of health care that has developed in the US over the last hundred years. The American Medical Association historically has viewed a system of private medical insurance based on fee-for-service payment of physicians as, 'foresighted, American, economical' (26). Systems involving salaried physicians and prepayment for medical services were seen as representing 'sovietism' and were explicitly labelled as unethical (27). 
The British National Health Service (NHS) presents quite a different history. To a large extent, it was the perception of the social inequities inherent in a system of medical care that links access to care with the ability to pay that led to the development of the NHS. For many years, physicians in the NHS did not revert to supplemental fees, official or otherwise, to augment their salary. While a certain amount of queue-jumping based on ability to pay did occur, it was not perceived to present a major problem (28). However, recent NHS reforms have injected more market-based incentives into the NHS, leading some authors to suggest that ethical questions of this type may become more prevalent $(29,30)$.

In all modern societies, medical care has come to be a relatively scarce commodity. While in the UK a guaranteed basic level of medical care has been available to all regardless of the ability to pay, in the US it has been made available largely according to the ability to pay. The best of treatment in the US has always been available to those who can pay (either out of their own pocket or through their insurance). Those who can't pay are relegated to a second tier of publicly financed or charitable facilities that often provide excellent care but do not represent the best the system has to offer.

In Soviet society, high quality care (by relative standards) was also a scarce commodity. As with other scarce commodities in the Soviet Union, these services were available through the 'second economy' on an unofficial barter system. (We should not confuse the Soviet second economy with the black market, which represented yet another level of economic activity.) Consider the Russian family with a plugged toilet. It could take weeks before the state plumber would get around to coming and fixing it. On the other hand, if the family happened to have an extra sausage or bottle of vodka, the toilet would be fixed before dinner, often by the very same state plumber.

The Soviet second economy represented (and in many areas continues to represent) a relatively orderly economic system for the distribution of scarce goods and services. Through the effect of supply and demand, a system of prices was established, and it came commonly to be understood that payment in kind was expected. This was as true for food and clothing as it was for medical care.

It would seem then that physicians and patients in Soviet-dominated societies jointly participated in a fee-for-service system for medical care, albeit an unofficial one. From a Western perspective, this system places the physician on tenuous ethical ground, particularly when a gift or tip is required as a condition of service. It is easy to speak judgmentally of these extra payments as bribes, as many authors are wont to do (12). However, if we label the system of extra fees for Soviet physicians as unethical, we would be hard pressed to explain why the fee-for-service system that has existed in the United States does not also present similar, though less blatant, ethical questions. The unresolved question in both countries, and one that may hold increasing significance for the NHS, is: When does a physician demanding extra payment as a condition of treatment cross the line of ethical behaviour? A satisfactory answer to this question would be an important contribution to the ethical standards of all three systems.

\section{Acknowledgement}

This research was supported by a National Research Service Award from the US Agency for Health Care Policy and Research.

Donald A Barr, MD, PhD, is Visiting Scholar at the Stanford Center for Organizations Research, Stanford University, Stanford, California, USA.

\section{References}

(1) Field M G. Soviet socialized medicine. New York: The Free Press, 1967.

(2) Ryan M. Doctors and the state in the Soviet Union. New York: St Martin's Press, 1990.

(3) Amnesty International. Political abuse of psychiatry i the USSR. London: Amnesty Internationat International Secretariat, 1983.

(4) Bloch S, Reddaway P. Soviet psychiatric abuse: the shadow over world psychiatry. London: Gollancz, 1984

(5) Chodoff P. Ethical conflicts in psychiatry: the Soviet Union $\mathrm{v}$ the US. Hospital and community psychiatry 1985; 36: 925-928.

(6) Wilkinson G. Political dissent and 'sluggish' schizophrenia in the Soviet Union. British medical journal 1986; 293: 641-642.

(7) White C. The debasing of medicine in the Soviet Union. British medical journal 1986; 293: 1524.

(8) Veatch R M. Medical ethics in the Soviet Union. Hastings Center report 1989; 19, 2: 11-14.

(9) Korotkikh R V. Medical ethics: problems of theory and practice. The journal of medicine and philosophy 1989; 14: 269-282.

(10) Tsaregorodtsev G I, Ivanyushkin A Y. Trends in the development of medical ethics in the USSR. The journal of medicine and philosophy 1989; 14: 301-314.

(11) Smirnov I. Human health: from theory to practice. The journal of medicine and philosophy 1989; 14 251-259.

(12) Casileth B R, Vlassov V V, Chapman C C. Health care, medical practice, and medical ethics in Russia today. Fournal of the American Medical Association 1995; 273: 1569-1573.

(13) Barr D A. The professional structure of Soviet medical care. The American journal of public health 1995; 85: 373-378.

(14) See reference (8): 13.

(15) Ryan M. Remuneration of Soviet medical personnel. British medical journal 1987; 294: 1340-1341.

(16) See reference (15): 1340.

(17) Chazov E I. Current digest of the Soviet press 1987; 39, 15: 19 . 
(18) Korotkikh R V. The social and ethical implications of universal access to health care in Russia. Kennedy Institute of Ethics journal 1993; 3: 411-418.

(19) Schulz D S, Rafferty M P. Soviet health care and perestroika. The American journal of public health 1990; 80: 193-197.

(20) Blasszauer B. Medical ethics committees in Hungary. Hec forum 1991; 3: 277-283.

(21) Adam G. Gratuity for doctors and medical ethics. The journal of medicine and philosophy 1989; 14: 315-322.

(22) Field M G. The position of the Soviet physician: the bureaucratic professional. The Milbank quarterly 1989; 66 [suppl 2]: 182-201.

(23) Talyshinsky R, Khudyakova T. Baku woman tells how doctors, hospitals routinely extort money from patients. Current digest of the Soviet Press 1987; 39,41: 15.

(24) Rosenthal E. Irked by Medicare, doctors ask elderly to pay up. New York times [national ed] $1994 \mathrm{Feb} 15$ :
Al (col 2).

(25) Perlez J. Economic collapse leaves Ukraine with little to trade but its weapons. New York times [national ed] 1994 Jan 13: A5 (col 1).

(26) Anonymous. The committee on the costs of medical care [editorial]. Fournal of the American Medical Association 1932; 99: 1950-1952.

(27) Anonymous. The report of the Committee on the Costs of Medical Care [editorial]. Fournal of the American Medical Association 1932; 99, 24: 2034-2035.

(28) Whitehead M. Who cares about equity in the NHS? British medical journal 1994; 308: 1284-1287.

(29) Paton C. Present dangers and future threats: some perverse incentives in the NHS reforms. British medical journal 1995; 310: 1245-1248.

(30) Persaud R D. What future for ethical medical practice in the new National Health Service? Fournal of medical ethics $1991 ; 17$ : 10-18.

\section{News and notes}

\section{Strengthening ethics at the UKCC}

The UKCC is pleased to announce that a resolution of the concerns expressed by some council members about the handling of ethics following the UKCC's organisation review has been reached. There will be a standing ethics advisory group (final title to be confirmed), annual wide-ranging seminars/conferences and a designated UKCC professional officer with responsibility for ethical issues across the organisation.

These arrangements are consistent with the principles of the organisation review. They have been warmly welcomed by council members. Rita Lewis, consumer member of the council and member of the standards and ethics committee, described the new measures as a significant step forward in strengthening the handling of ethics within the UKCC. The new arrangements, as with all changes taking place following the organisation review, will continue to be reviewed as necessary.

\section{News and notes}

\section{FDA meeting: medical device update}

From 20-23 May 1996, at the Charles-de-Gaulle Hilton, Paris, France, there will be an international meeting on Food and Drug Administration (FDA), good manufacturing practice (GMP) and marketing regulations including the proposed new GMP requirements and how to comply with them.
The meeting is sponsored by the French Government.

For further information contact: Zena Barrick, Medical Device Technology, Advanstar House, Park West, Sealand Road, Chester CH1 4RN, UK: Tel +44 (0) 1244378 888; Fax +44 (0)1244370 011. 